\title{
Determination of Insulin in saline by RP- HPLC combined with UV
}

\section{UV kombine RP-HPLC ile İzotonik Serum Fizyolojikte İnsülin Tayini}

\section{Merve Nenni ${ }^{1^{*}}$ \\ Orcid: 0000-0003-3165-1060}

${ }^{1}$ Cukurova University, Faculty of Pharmacy, Department of Analytical Chemistry, Adana, Turkey

\section{Corresponding author:}

Merve Nenni

Cukurova University, Faculty of Pharmacy, Department of Analytical Chemistry, Sarıçam, Adana, Turkey

Tel: +90 3223387334

Fax: +903223387336

Email:mnenni@cu.edu.tr merve.ecz@gmail.com

\begin{abstract}
In the treatment of type I diabetes mellitus, insulin is widely used intravenously. This study aims to develop an innovative, fast and simple analysis technique for insulin determination in $0.9 \% \mathrm{NaCl}$ solution samples. Insulin was analyzed by HPLC with a UV detector. The method has been validated according to FDA guidelines and satisfactory results have been observed. Samples were manually injected into the HPLC system using ACE $5 \mu \mathrm{m} \mathrm{C} 18100 \AA$ LC column $(250 \mathrm{x} 4.6$ $\mathrm{mm}$ ). The mobile phase was a mixture of acetonitrile: phosphate buffer $(\mathrm{pH} 3.0$, $10 \mathrm{mM})(50: 50 \mathrm{v} / \mathrm{v})$. The injection volume is $20 \mu \mathrm{L}$. UV detection was carried out at $240 \mathrm{~nm}$. Based on validation studies, the method was found as specific, linear, precise, accurate, and sensitive.
\end{abstract}

Keywords: Regular insulin, HPLC, saline solution, validation, UV.

\section{ÖZET}

Tip I diabetes mellitus tedavisinde insülin yaygın olarak intravenöz olarak kullanılmaktadır. $\mathrm{Bu}$ çalışmanın amacı, \% $0.9^{\prime}$ luk $\mathrm{NaCl}$ solüsyon örneklerinde insülin tayini için yenilikçi, hızlı ve basit bir analiz tekniği geliştirmektir. İnsülin, UV detektörlü HPLC ile analiz edilmiştir. Yöntem, FDA yönergelerine göre onaylanmış ve tatmin edici sonuçlar gözlenmiştir. Örnekler, ACE $5 \mu \mathrm{m}$ C18 $100 \AA$ LC kolonu (250 x 4.6 mm) kullanılarak HPLC sistemine manuel olarak enjekte edilmiştir. Mobil faz, bir asetonitril: fosfat tamponu (pH 3.0, 10 $\mathrm{mM})(50: 50 \mathrm{v} / \mathrm{v})$ karışımıdır. Enjeksiyon hacmi $20 \mu \mathrm{L}$ 'dir. UV saptaması 240 nm'de gerçekleştirilmiştir. Yöntemin, özgün, doğrusal, kesin, doğru ve duyarlı bir yöntem olduğu validasyon çalışmalarıyla ortaya konulmuştur.

Anahtar Kelimeler: Reguler insulin, HPLC, izotonik serum fizyolojik, validasyon, UV. 


\section{Introduction}

After the food is digested, it is broken down into sugar by the enzymes in our body. Sugar (glucose) is transported by blood flow to all parts of the body. Sugar, the main food source of our body, must enter the body cells (muscle, fat and liver cells) from the blood in order to provide energy. Insulin is a hormone secreted by the beta cells of an organ called the pancreas, located under and behind the stomach in our body. It allows the sugar in the blood to leave the blood and enter the cell. Thus, the level of sugar in the blood does not increase. In a non-diabetic person, after each food intake, the pancreas produces insulin to transform the nutrients taken into energy. This means that all people are dependent on insulin. In those with diabetes, the pancreas does not produce enough insulin or the insulin produced is not used by target cells (muscle, fat and liver cells). In this case, we need to provide insulin, which is vital for our body, from outside. It should not be forgotten that insulin is a life-saving drug and a healthier life will be lived with the injection. Insulin is the first protein sequenced by Frederick Sanger in 1955 [1, 2]. The molecular weight of insulin is $5.8 \mathrm{kDa}$. In its structure, there are two peptide chains containing the A chain (21 amino acids) and the B chain (30 amino acids) connected by two disulfide bridges (Figure 1) [3]. Human insulin was produced by recombinant DNA technology where an attenuated Escherichia coli bacterium is used as a vector to produce A and B chains. By connecting these chains with cross bridges, recombinant human insulin is obtained. In patients having type I diabetes mellitus, the pancreas cannot produce enough insulin to manage the glucose level. Recombinant human insulin, i.e., regular insulin, is used in the treatment of type I diabetes mellitus $[4,5]$. The insulin formulation can be administered by subcutaneous, intramuscular, and intravenous injection.

HPLC is a very powerful tool for the analysis of peptides and proteins. Due to the recognition of this fact and the emergence of favorable chromatographic conditions, there has been an increase in the use of HPLC for peptide and protein analyzes. Analysis of insulins has traditionally been done by biological tests [6]. Today, it is widely accepted that suitably developed chromatographic analysis is superior to biological analysis for many applications $[7,8]$. In literature, insulin concentrations in plasma, pharmaceutical products, and saline were determined using high-performance liquid chromatography (HPLC) combined with UV detection and mass spectrometry (MS) [4, 9-14]. As expected for MS, the sensitivity of the developed methods was more satisfactory than the ones for UPLC-UV. However, as a basic concept, advanced analytical techniques like MS may cost higher financial management sources and they may not be available for routine applications on regular laboratories.

\section{Insulin}

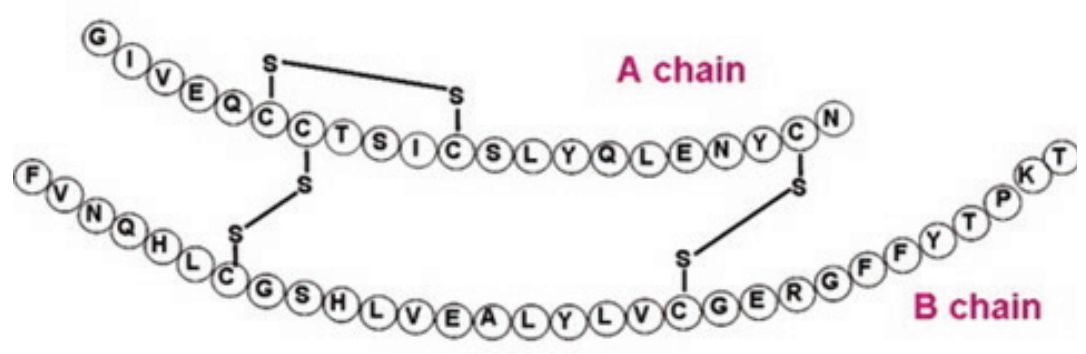

$\begin{array}{lllll} & \text { A8 } & \text { A9 } & \text { A10 } & \text { B30 } \\ \text { Human } & \text { Thr } & \text { Ser } & \text { lle } & \text { Thr } \\ \text { Porcine } & \text { Thr } & \text { Ser } & \text { lle } & \text { Ala } \\ \text { Bovine } & \text { Ala } & \text { Ser } & \text { Val } & \text { Ala } \\ \text { Sheep } & \text { Ala } & \text { Gly } & \text { Val } & \text { Ala }\end{array}$

Figure 1: Structure of insulin 
Table 1. HPLC analysis of insulin

\begin{tabular}{|c|c|c|c|c|c|c|}
\hline References & $\begin{array}{l}\text { Publication } \\
\text { Year }\end{array}$ & Column & Mobile Phase & $\begin{array}{c}\text { Detection } \\
\text { method }\end{array}$ & Sample Matrix & $\begin{array}{l}\text { Analyses } \\
\text { time }\end{array}$ \\
\hline$[4]$ & 2019 & $\begin{array}{c}\text { Agilent RRHD } \\
300 \AA \mathrm{SB}-\mathrm{C} 18 \\
(50 \times 2.1 \mathrm{~mm}, 1.8 \\
\mu \mathrm{m}\end{array}$ & $\begin{array}{c}\text { from ACN with } 0.2 \% \\
\text { TFA: water with } 0.2 \% \text { TFA } \\
(22: 78, \mathrm{v} / \mathrm{v}) \text { to ACN with } \\
0.2 \% \text { TFA:water with } 0.2 \\
\text { TFA }(95: 5, \mathrm{v} / \mathrm{v})\end{array}$ & MS/MS & $\begin{array}{l}\text { Pharmaceutical } \\
\text { Dosage Form }\end{array}$ & $\begin{array}{l}\text { Insulin is } \\
\text { within } 3 \\
\text { minutes }\end{array}$ \\
\hline [9] & 2012 & $\begin{array}{l}\text { Ace C18 }(250 \times \\
4.6 \mathrm{~mm}, 5 \mu \mathrm{m})\end{array}$ & $\begin{array}{c}\text { Acetonitrile: } 0.2 \mathrm{M} \text { sodium } \\
\text { sulfate buffer pH was } \\
\text { adjusted to } 2.4 \text { by using } \\
\text { ortho-phosphoric acid ( } 25: 75 \\
\mathrm{v} / \mathrm{v})\end{array}$ & $\begin{array}{l}\text { Diode Array } \\
\text { Detector at } \\
206 \mathrm{~nm}\end{array}$ & Human plasma & $\begin{array}{l}\text { Insulin is } \\
\text { within } 14 \\
\text { minutes }\end{array}$ \\
\hline$[10]$ & 2010 & $\begin{array}{c}\text { Phenomenex } \\
\text { C18 }(250 \times 4.6 \\
\mathrm{mm}, 5 \mu \mathrm{m})\end{array}$ & $\begin{array}{c}\text { Acetonitrile: } 0.2 \mathrm{M} \text { sodium } \\
\text { sulfate buffer } \mathrm{pH} \text { was } \\
\text { adjusted to } 2.4 \text { by using } \\
\text { ortho-phosphoric acid ( } 25: 75 \\
\mathrm{v} / \mathrm{v})\end{array}$ & $\begin{array}{l}\text { Diode Array } \\
\text { Detector at } \\
206 \mathrm{~nm}\end{array}$ & $\begin{array}{l}\text { Pharmaceutial } \\
\text { preparation }\end{array}$ & $\begin{array}{l}\text { Insulin is } \\
\text { within } 14 \\
\text { minutes }\end{array}$ \\
\hline$[11]$ & 2010 & $\begin{array}{l}\text { Hypersil BDS } \\
\text { C-18 }\end{array}$ & $\begin{array}{c}\text { A (aqueous solution of } 28.3 \\
\text { anhydrous } \mathrm{Na}_{2} \mathrm{SO}_{4} \mathrm{~g} / \mathrm{L}, \mathrm{pH} \\
2.3) \text { and solution } \mathrm{B}(28.5 \\
\mathrm{g} \text { anhydrous } \mathrm{Na}_{2} \mathrm{SO}_{4} \mathrm{~g} / \mathrm{L} \text { in } \\
50: 50 \text { mixture of water and } \\
\text { acetonitrile, } \mathrm{pH} 2.3) \text { in a ratio } \\
48: 52(\mathrm{v} / \mathrm{v}) \text { at } 45-50{ }^{\circ} \mathrm{C}\end{array}$ & $\begin{array}{l}\text { UV detection } \\
\text { at } 216 \mathrm{~nm}\end{array}$ & $\begin{array}{c}\text { Bulk and } \\
\text { Pharmaceutical } \\
\text { Dosage Form }\end{array}$ & $\begin{array}{l}\text { Insulin is } \\
\text { within } 20 \\
\text { minutes }\end{array}$ \\
\hline [12] & 2006 & $\begin{array}{l}\text { Waters Columns } \\
\mu \text { bondapak C18 } \\
(3.9 \times 30 \mathrm{~mm}, 10 \\
\mu \mathrm{m})\end{array}$ & $\begin{array}{l}\text { Acetonitrile:phosphate buffer } \\
\qquad(30: 70 \mathrm{v} / \mathrm{v})\end{array}$ & $\begin{array}{l}\text { UV-VIS } \\
\text { detection at } \\
2280 \mathrm{~nm}\end{array}$ & $\begin{array}{l}\text { Pharmaceutical } \\
\text { Dosage Form }\end{array}$ & $\begin{array}{l}\text { Insulin is } \\
\text { within } 20 \\
\text { minutes }\end{array}$ \\
\hline$[13]$ & 2005 & $\begin{array}{l}\text { XTerra RP18 } \\
\text { C18 }(250 \times 4.6 \\
\mathrm{mm}, 5 \mu \mathrm{m})\end{array}$ & $\begin{array}{c}\text { from ACN:water with } \\
0.1 \% \text { TFA }(30: 70, \mathrm{v} / \mathrm{v}) \text { to } \\
\text { ACN:water with } 0.1 \text { TFA } \\
(40: 60, \mathrm{v} / \mathrm{v})\end{array}$ & $\begin{array}{l}\text { UV detection } \\
\text { at } 214 \mathrm{~nm}\end{array}$ & $\begin{array}{l}\text { Insulin-loaded } \\
\text { nanoparticulates } \\
\text { composed of } \\
\text { polyelectrolytes }\end{array}$ & $\begin{array}{l}\text { Insulin is } \\
\text { within } 6 \\
\text { minutes }\end{array}$ \\
\hline$[14]$ & 2004 & $\begin{array}{c}\text { JupiterC1S, C18 } \\
(250 \times 4.6 \mathrm{~mm}, \\
5 \mu \mathrm{m})\end{array}$ & $\begin{array}{l}\text { ACN with } 0.1 \% \text { TFA:water } \\
\text { with } 0.1 \% \text { TFA }(31: 69, \mathrm{v} / \mathrm{v})\end{array}$ & $\begin{array}{l}\text { UV detection } \\
\text { at } 280 \mathrm{~nm}\end{array}$ & $\begin{array}{l}\text { Normal Saline } \\
\text { Infusion in } \\
\text { polyvinyl chloride } \\
\text { (PVC) plastic }\end{array}$ & $\begin{array}{c}\text { No } \\
\text { informetion }\end{array}$ \\
\hline
\end{tabular}

To present the already published methodologies, Table 1 provides a summary. As it is seen on table, there is no method for analysis of insulin in a polypropylene bag containing $0.9 \% \mathrm{NaCl}$ (known as saline) and the analysis time for the reported methods reaches almost 20 minutes. Therefore, this present study aimed to develop and validate a method using a simple, fast, precise, accurate, and specific reverse phase HPLC-DAD test.

\section{Materials and Methods}

\subsection{Chemicals}

Regular insulin was obtained from the Humulin $\mathrm{R}$ U-100 injection formulation from Lilly pharmaceutical company. Analytical grade acetonitrile and sodium phosphate monobasic were purchased from
Merck (Darmstadt, Germany). All the solutions were prepared by using Milli-Q water. Turkey. $0.9 \%$ isotonic solutions, polypropylene bag, a pharmaceutical warehouse (Polifarma, Turkey) was purchased from local pharmacies. The $\mathrm{pH}$ meter (OHAUS starter5000) was used to adjust the $\mathrm{pH}$ of the buffer solutions.

\subsection{Apparatus}

Analysis of insulin from an isotonic solution containing $0.9 \% \mathrm{NaCl}$, that is, saline, was analyzed by reverse-phase high-performance liquid chromatography (RP-HPLC). RP-HPLC system (Agilent 1220 Infinity II) consisting of a gradient pump, a degasser, a manual injection system, and a UV detector was used. IKA Vortex Genius (IKA, Germany) was used to vortex the samples. 


\subsection{Preparing mobile phase buffer of HPLC analysis}

To prepare $10.0 \mathrm{mM}$ phosphate buffer, $1.56 \mathrm{~g}$ of sodium dihydrogen phosphate $\left(\mathrm{NaH}_{2} \mathrm{PO}_{4}\right)$ was dissolved in approximately $800 \mathrm{~mL}$ of water. The $\mathrm{pH}$ of the solution was adjusted to $\mathrm{pH} 3.0$ with o-phosphoric acid. Then the volume was filled up to $1000 \mathrm{~mL}$ with water.

\subsection{Chromatographic conditions}

Separations were carried on a Phenomenex $5 \mu \mathrm{m}$ C18 $100 \AA$ LC Column $(250 \times 4.6 \mathrm{~mm})$. The flow rate was $1.0 \mathrm{~mL} \mathrm{~min} \mathrm{~m}^{-1}$ while using isocratic elution with the mobile phase [acetonitrile: phosphate buffer $(\mathrm{pH} 3.0,10 \mathrm{mM})(50: 50 \mathrm{v} / \mathrm{v})]$ mixture. The injection volume was $20 \mu \mathrm{L}$ and UV detection was performed at $214 \mathrm{~nm}$.

\subsection{Standard stock solutions}

Humulin RU-100 contains 100 units (IU) per mL. Also, 1 IU of insulin is known to be equivalent to 24 $\mathrm{mg}$ of insulin. The standard stock solutions of insulin (5 and $50 \mathrm{IU}$ ) were prepared. All of the standard solutions were kept at $4{ }^{\circ} \mathrm{C}$ during analysis and were prepared freshly each day. Appropriate dilutions were applied using micropipettes to prepare calibration standards and sample solutions.

\subsection{Preparing Calibration Standards}

Eppendorf Research ${ }^{\circledR}$ plus micropipettes (adjustable for maximum $10 \mu \mathrm{L}, 100 \mu \mathrm{L}$, and $1000 \mu \mathrm{L}$ volumes) were used to prepare the calibration standards. Six different sets of calibration standards containing between $0.1,0.25,0.5,0.75,1.0,2.0,3.0$, and 5 IU of insulin were prepared in the microcentrifuge tubes by saline. The solutions having a concentration below 1 IU for insulin were prepared by using the diluted standard stock solutions (5 IU of insulin). All of the standard stock solutions were prepared in microcentrifuge tubes and the volume was filled up to $1000 \mu \mathrm{L}$ with the mobile phase. Finally, 48 solutions were prepared for calibration curves having eight points including six sets $(n=6)$.

These calibration standards were injected into the HPLC system by manual injection. Peak areas of insulin were integrated automatically by ChemStaion software. Peak areas were plotted against the concentrations of insulin by using MS Excel. Standard errors of slope and intercept were evaluated for the linearity of the proposed method. Mean values of slope and intercept were used to find the main calibration equation for the analysis of insulin spiked saline samples.

\subsection{Recovery studies}

Two different sample groups were prepared. The first group was saline samples and the second group was aqueous solutions of insulin. Both of these groups were prepared three times and contained $0.25,1.0$, and 3.0 IU insulin. After the solutions were prepared with saline or water, $500 \mu \mathrm{L}$ of the mobile phase of HPLC was added to each solution to fill the final volume to $1000 \mu \mathrm{L}$. The triplicate peak areas for the two groups were compared for each concentration level.

\subsection{Analytical Method Validation}

The developed method was validated according to the FDA guidelines and the calibration curves, sensitivity, precision, accuracy, and selectivity of the method were evaluated [15] .

\section{Results and Discussion}

Regular insulin is one of the well-known and widely used in the treatment of type I diabetes mellitus. Generally, patients hospitalized in the intensive care unit are given 0.5-2 units per $\mathrm{mL}$ per hour via infusion pumps. For this, insulin infusion is given intravenously by preparing the bag in $0.9 \%$ sodium chloride. It is recommended to be stored in the refrigerator at $2-8^{\circ} \mathrm{C}$ before opening the manuals. After opening, it is recommended to be stored below 30 - $\mathrm{C}$ and used within 28 days. Insulin is stable when diluted in normal saline for clinical use. However, it is thought that there is a loss of insulin in saline bags, and the insulin solutions in the bag are renewed [5, 14, 16-19]. Therefore, it is important to quickly and simply analyze insulin in saline samples for subsequent studies. With this study, it is planned to develop a new approach to insulin analysis in saline samples in polypropylene bags.

\subsection{Optimization of the Chromatographic \\ Conditions}

The previously reported studies were overviewed and it was decided to use phosphate buffer ( $\mathrm{pH}$ : 3.0) and acetonitrile mixture as the mobile phase. A short $\mathrm{C} 18$ column [Phenomenex LC Column (250 x $4.6 \mathrm{~mm}, 5$ $\mu \mathrm{m}, 100 \AA$ )] was used. Since the aim was to analyze 
insulin from saline samples, a mixture of various acetonitrile and phosphate buffer solutions was injected into the insulin saline samples. It was observed that the water-soluble interference in the saline solution was easily eluted with the dead volume, and from baseline. The optimum mobile phase conditions were found to be acetonitrile: phosphate buffer $(\mathrm{pH}$ $3.0,10 \mathrm{mM})(50: 50 \mathrm{v} / \mathrm{v})$ where the total analysis time was shorter than 6.0 minutes. The chromatograms of blank, spiked sample, and standard solutions were given in Figure 2. Since the stability of insulin is already known on previous studies [14], the injection stability of insulin was investigated in the scope of this study. The prepared calibration standards were dissolved in the mobile phase and stored at ambient temperature $\left(24-28{ }^{\circ} \mathrm{C}\right)$. Then, these solutions were injected after 24 hours. The peak areas were compared with the previous injections. This process was applied three times for 1 IU of the insulin calibra- tion standard. The results of these stability studies are given in Table 2 and the percent ratios are within the acceptance range of $90-110 \%$. Also, the system compatibility of the developed HPLC method is given in Table 2 . These results show that the system suitability of the developed method meets the requirements and that the prepared solutions can be injected within 24 hours when kept in a laboratory condition.

\subsection{Method Validation}

\subsubsection{Linearity and sensitivity of the developed method}

The linearity of an analytical procedure is its ability (within a given range) to obtain test results, which are directly proportional to the concentration (amount) of analyte in the sample. The calibration curves were constructed within the range between 0.1 and 5.0

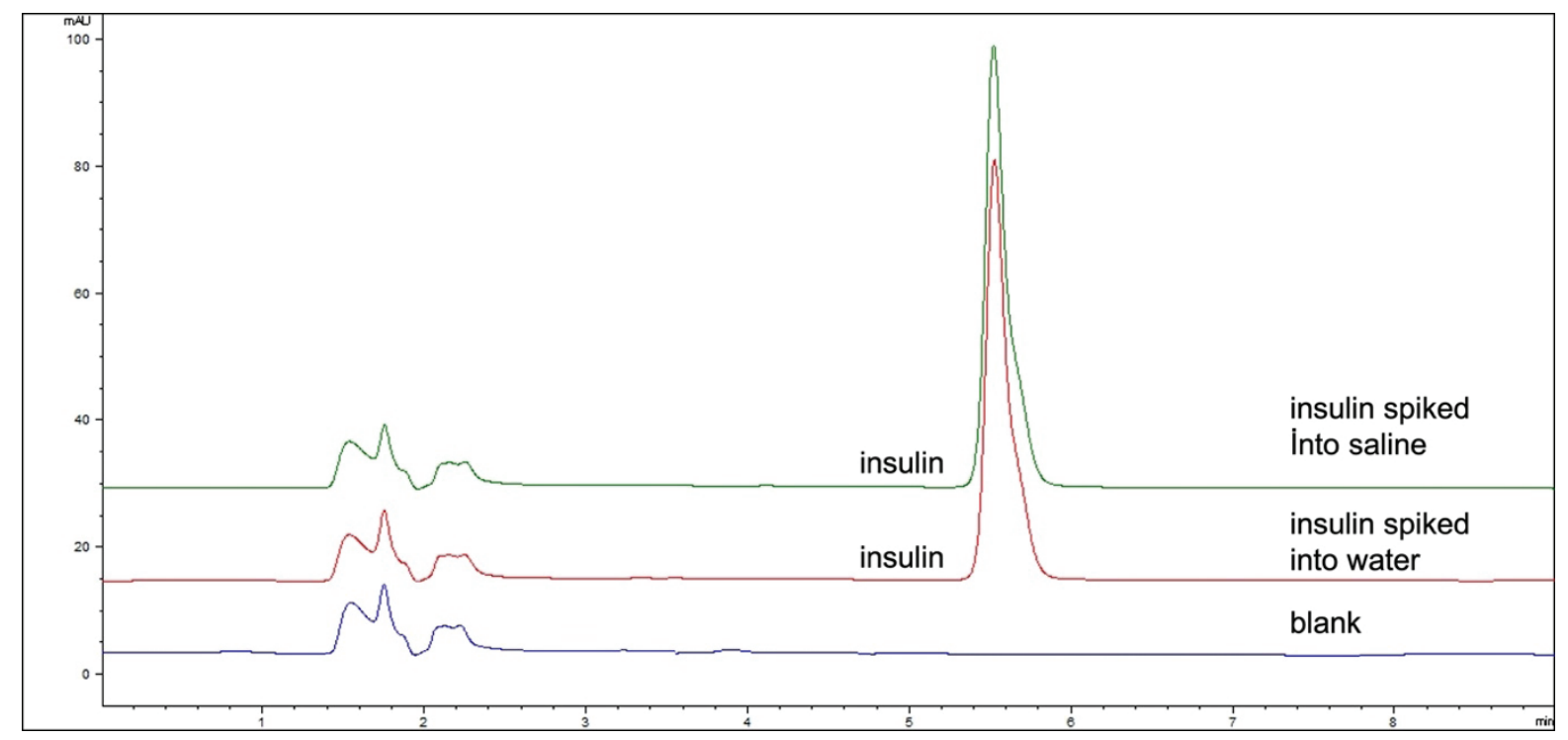

Figure 2: The overlaid chromatograms of blank saline sample, insulin spiked into the water and spiked into saline samples under experimental conditions. Insulin concentration is $1 \mathrm{IU} \mathrm{mL}^{-1}$

Table 2. System suitability parameters of insulin for the proposed method $(n=6)$

\begin{tabular}{ccc}
\hline & Found & Requirements \\
\hline Injection repeatability (RSD of $\left.\mathrm{r}_{\mathrm{r}}\right)$ & $0.21 \%$ & $<1 \%$ \\
Capacity Factor $\left(\mathrm{k}^{\prime}\right)$ & 5.985 & $1<\mathrm{k}^{\prime}<10$ \\
Efficiency $(\mathrm{N})$ & 4507 & $>2000$ \\
Tailing Factor & 1.29 & $<1.5$ \\
Injection stability (after 24 hours at ambient temperature) & $102.06 \% 1.15$ \\
\hline
\end{tabular}


IU where the method is linear and it is possible to analyze insulin in saline solutions up to $24 \mathrm{~h}$. The signal-to-noise ratios of 3:1 and 10:1 were taken as limit of detection (LOD) and limit of quantification (LOQ), respectively [20]. The linearity and sensitivity of the developed method were summarized in Table 3 . The chromatograms of calibration curves are given in Figure 3.

\subsubsection{Accuracy and precision of the developed method}

Three different concentrations of insulin $(0.25,1.0$, and $3.0 \mathrm{IU}$ ) within the linear range were analyzed three consecutive days (inter-day studies) and three times within the same day (intra-day studies). The procedure was repeated six times for three different concentration levels within the linear range. The relative standard deviation (RSD) and the bias of intra- and inter-day studies were calculated by us-

Table 3. Linearity of the developed method $(n=6)$

\begin{tabular}{cc}
\hline Regression equation* & $\mathrm{y}=713.852 \mathrm{x}+36.661$ \\
\hline Standard error of intercept & 0.6221 \\
Standard error of slope & 0.3815 \\
Regression coefficient $\left(\mathrm{R}^{2}\right)$ & 0.9993 \\
Range $\left(\mu \mathrm{g} \mathrm{mL}^{-1}\right)$ & $0.1-5$ \\
Number of data points & 8 \\
LOD $\left(\mu \mathrm{g} \mathrm{mL} \mathrm{mL}^{-1}\right)$ & 0.0064 \\
LOQ $\left(\mu \mathrm{g} \mathrm{mL} \mathrm{mL}^{-1}\right)$ & 0.0213
\end{tabular}

* Based on six calibration curves where y: peak area of insulin and $\mathrm{x}$ : concentration of insülin as IU, LOQ: Limit of quantification, LOD: Limit of detection

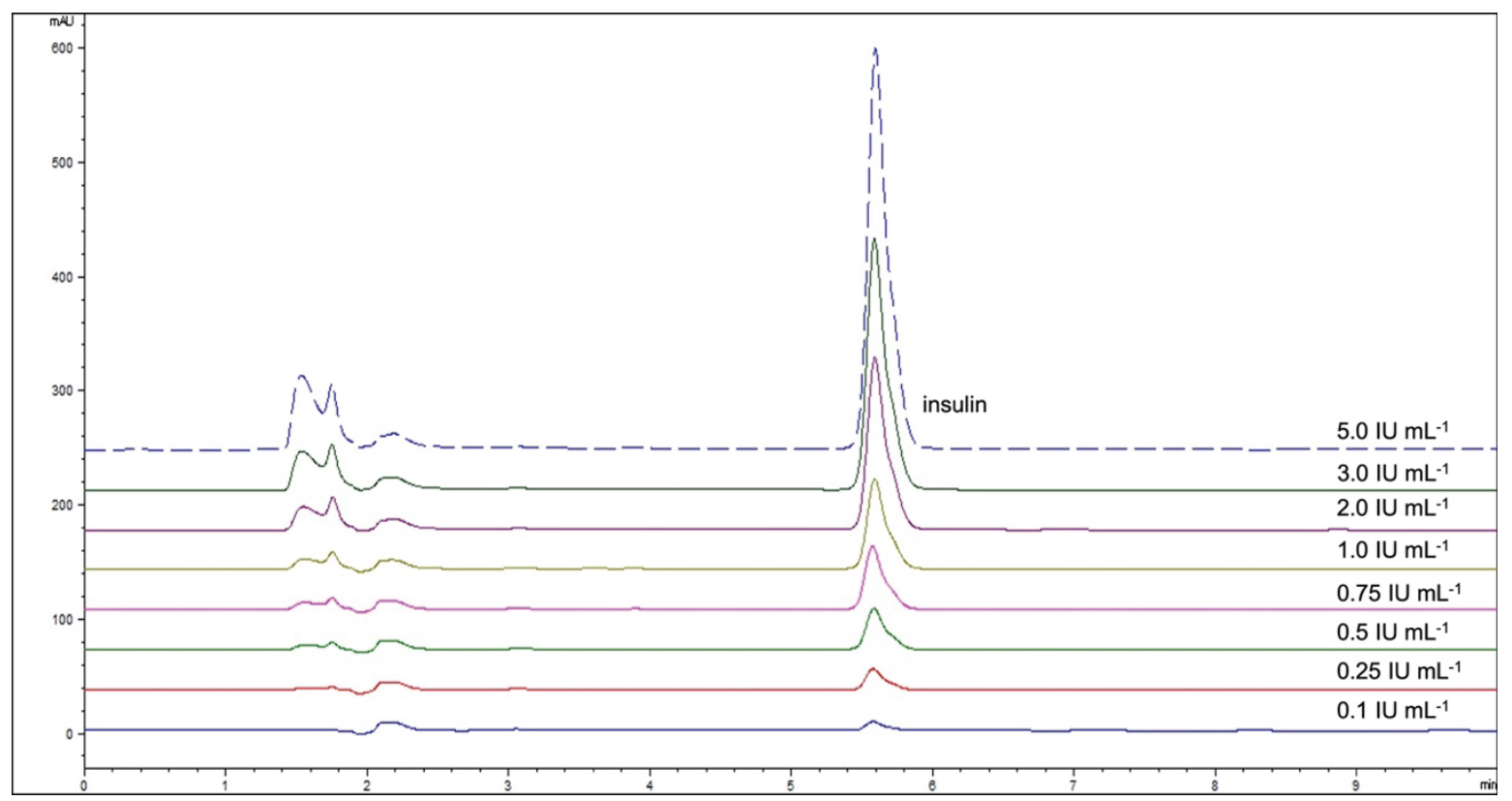

Figure 3: The overlaid chromatograms of calibration curve samples $(0.25-5 \mathrm{IU}$ of insulin) under experimental conditions: Mobile phase: acetonitrile:phosphate buffer $(\mathrm{pH} 3.0,10 \mathrm{mM})(50: 50 \mathrm{v} / \mathrm{v})$, flow rate: $1 \mathrm{~mL}$ min-1, injection volume: $20 \mu \mathrm{L}$, detection wavelength: $214 \mathrm{~nm}$. 
ing regression equations. The biases of intra- and inter-day studies were between -0.316 and 1.641 . The relative standard deviations of intra- and interday studies were between 0.295 and 1.457 (Table 4). These results indicate that the developed method was accurate and precise.

\subsubsection{Recovery of the developed method}

The recovery of the developed method was investigated for three different concentration levels $(0.25$, 1.0, and $3.0 \mathrm{IU}$ ) of saline samples as described in the experimental section. The procedure was repeated three times for three different concentration levels within the linear range. The recoveries were $100.16 \%$ (SD: 0.16), $100.14 \%$ (SD: 0.05) and 99.90 $\%$ (SD:0.69) (SD: Standard deviation, $\mathrm{n}=3$ ) for the plasma samples containing $0.25,1.0$ and $3.0 \mathrm{IU}$ of insulin, respectively (Table 5). The results show that it is successful for the recovery of insulin from saline samples.

\subsubsection{Selectivity of the developed method}

The selectivity of an assay is a measure of the extent to which the method can determine a particular com- pound in the analyzed matrices without interference from matrix components. Therefore, the chromatograms obtained from blank, spiked insulin into saline, and spiked insulin into the water as described in the recovery section were compared (Figure 2). The interference peaks coming from matrix components were tracked to show if they interfere with the peak of insulin. From the water-soluble matrix components and dead volume, insulin was separated in 5.58 minutes.

\subsection{Analysis of spiked plasma samples}

Insulin spiked saline samples $(0.25,1.0$, and $3.0 \mathrm{IU}$ insulin) were prepared as described in the experimental section. These solutions were analyzed by the developed HPLC method and the results were evaluated by using regression equation (Table 3 ) obtained from calibration standards. The analysis results were given in Table 5. As can be seen from the results, the developed RP-HPLC method can be used successfully for NS analysis in saline samples.

Table 4. Precision and Accuracy of Insulin in Human Plasma Analysis of spiked saline samples ( $\mathrm{n}=6$ )

\begin{tabular}{|c|c|c|c|c|c|c|}
\hline \multirow{2}{*}{$\begin{array}{l}\text { Added insulin into the } \\
\text { blank saline samples }\end{array}$} & \multicolumn{2}{|c|}{$\begin{array}{c}0.25 \\
\text { IU }\end{array}$} & \multicolumn{2}{|c|}{$\begin{array}{l}1.0 \\
\text { IU }\end{array}$} & \multicolumn{2}{|c|}{$\begin{array}{l}3.0 \\
\text { IU }\end{array}$} \\
\hline & intraday & interday & intraday & interday & intraday & interday \\
\hline $\begin{array}{l}\text { Found insulin in the blank } \\
\text { saline samples* }\end{array}$ & $\begin{array}{c}0.249 \pm 0.001 \\
\text { IU }\end{array}$ & $\begin{array}{c}0.249 \pm \\
0.001 \\
\mathrm{IU}\end{array}$ & $\begin{array}{c}1.016 \pm 0.003 \\
\mathrm{IU}\end{array}$ & $\begin{array}{c}1.013 \pm 0.002 \\
\text { IU }\end{array}$ & $\begin{array}{c}3.049 \pm 0.007 \\
\text { IU }\end{array}$ & $\begin{array}{c}3.040 \pm 0.003 \\
\text { IU }\end{array}$ \\
\hline Bias of the analysis** & -0.316 & -0.223 & 1.637 & 1.030 & 1.641 & 1.338 \\
\hline $\begin{array}{c}\text { Relative standard deviation } \\
\text { of the results }\end{array}$ & 1.342 & 1.457 & 0.653 & 0.567 & 0.559 & 0.295 \\
\hline
\end{tabular}

${ }^{*}$ Found : mean \pm standard error $(n=6)$

${ }^{* *}$ Bias : [(Found - Added) / Added] x 100

Table 5. Analysis of spiked saline samples $(n=3)$

\begin{tabular}{cccc}
\hline Added insulin into the blank saline samples & $0.25 \mathrm{IU}$ & $1.0 \mathrm{IU}$ & $3.0 \mathrm{IU}$ \\
\hline Found insulin in the blank saline samples* & $0.249 \pm 0.001$ & $1.013 \pm 0.003$ & $3.045 \pm 0.007$ \\
Bias of the analysis** & $\mathrm{IU}$ & 1.334 & 1.489 \\
Relative standard deviation of the results & -0.270 & 0.662 & 0.454 \\
Recovery (\%) & 1.336 & $100.14 \pm 0.05$ & $99.90 \pm 0.69$ \\
\hline
\end{tabular}

*Found : mean \pm standard error $(\mathrm{n}=3)$

${ }^{* *}$ Bias : [(Found - Added) / Added] x 100 


\section{Conclusion}

Pharmaceutical analysis is one of the main components on pharmaceutical development processes. Analytical scientists and analyst in pharmaceutical companies perform quality control of pharmaceuticals as a regular application. Compared to electrochemistry, capillary electrophoresis, and UV-Spectroscopy methods, HPLC is one of the most versatile technique as a result of its reproducibility and capability of preventing the analyte peak coming from matrix components [21]. In this study, a fast and specific method was developed for determination of regular insulin. With this study, since the analysis time of insulin is shortened, it will be easier and faster to apply compared to other methods. In addition, insulin analysis was performed for the first time using polypropylene saline bags, which are widely used today and have less interaction with drugs. The proposed and validated method could be used in the analysis of human insulin in saline bags on quality control applications.

\section{Acknowledgement}

\section{References}

1. Sanger F, Thompson E, and Kitai R: The amide groups of insulin. Biochemical Journal 1955, 59(3): 509.

2. https://www.turkdiab.org/diyabet-hakkinda-hersey. asp?lang=TR\&id=52 (07.04.2021)

3. Mayer JP, Zhang F, and DiMarchi RD: Insulin structure and function. Peptide Science: Original Research on Biomolecules 2007, 88(5): 687-713.

4. Moussa B, Farouk F, and Azzazy H: A validated RP-HPLC method for the determination of recombinant human insulin in bulk and pharmaceutical dosage form. E-Journal of Chemistry 2010, 7(S1): 449-457.

5. Bettelheim FA and Landesberg JM: Laboratory experiments for introduction to general, organic and biochemistry. Cengage Learning; Boston, USA, 2012.

6. Stewart G: Historical review of the analytical control of insulin. Analyst 1974, 99(1185): 913-928.

7. Calam D: Applications of chromatography in the standardization and control of biological products. Journal of Chromatography A 1978, 167: 91-108.

8. Smith Jr H, Atkins L, Binkley D, Richardson W, and Miner D: A universal HPLC determination of insulin potency. Journal of liquid chromatography 1985, 8(3): 419-439.

9. Legg KM, Labay LM, Aiken SS, and Logan BK: Validation of a Fully Automated Immunoaffinity Workflow for the Detecti- on and Quantification of Insulin Analogs by LC-MS-MS in Postmortem Vitreous Humor. Journal of analytical toxicology 2019, 43(7): 505-511.

10. Yilmaz B, Kadioglu Y, and Capoglu I: Determination of insulin in humans with insulin-dependent diabetes mellitus patients by HPLC with diode array detection. Journal of chromatographic science 2012, 50(7): 586-590.

11. Yilmaz B and Kadioglu Y: Development and validation of HPLC method for determination of human insulin in pharmaceutical preparation. International Journal of Pharmaceutical Sciences Review and Research 2010, 2(2): 40-43.

12. Salem LI, Bedmar M, Medina M, and Cerezo A: Insulin evaluation in pharmaceuticals: variables in RP-HPLC and method validation. Journal of Liquid Chromatography \& Related Technologies 1993, 16(5): 1183-1194.

13. Sarmento B, Ribeiro A, Veiga F, and Ferreira D: Development and validation of a rapid reversed-phase HPLC method for the determination of insulin from nanoparticulate systems. Biomedical Chromatography 2006, 20(9): 898-903.

14. Lim SC, Roberts MJ, Paech MJ, Peng L, and Jones A: Stability of insulin aspart in normal saline infusion. Journal of Pharmacy Practice and Research 2004, 34(1): 11-13.

15. http://www.fda.gov/downloads/Drugs/GuidanceComplianceRegulatoryInformation/Guidances/UCM368107.pdf (17.03.2021)

16. Hirsch JI, Wood JH, and Thomas RB: Insulin adsorption to polyolefin infusion bottles and polyvinyl chloride administration sets. American journal of hospital pharmacy 1981, 38(7): 995-997.

17. Weber SS and Wood WA: Insulin adsorption controversy. Drug Intelligence \& Clinical Pharmacy 1976, 10(4): 232-233.

18. Schildt R, Ahlgren T, Berghem L, and Wendt Y: Adsorption of insulin by infusion materials. Acta Anaesthesiologica Scandinavica 1978, 22(5): 556-562.

19. Twardowski ZJ, Nolph KD, McGary TJ, Moore HL, Collin P, Ausman RK, and Slimack WS: Insulin binding to plastic bags: a methodologic study. American journal of hospital pharmacy 1983, 40(4): 575-579.

20. Bonfilio R, Cazedey ECL, Araújo MBd, and Nunes Salgado HR: Analytical Validation of Quantitative High-Performance Liquid Chromatographic Methods in Pharmaceutical Analysis: A Practical Approach. Critical Reviews in Analytical Chemistry 2012, 42(1): 87-100.

21. Watson DG: Pharmaceutical AnalysisA Textbook for Pharmacy Students And Pharmaceutical Chemists. Churchill Livingstone; Edinburgh, Scotland, 1999. 